\title{
The East-West Ideological Struggle and the Politics of African Decolonization in the United Nations: Historical Analysis
}

\author{
Aderemi Opeyemi Ade-Ibijola \\ Department of International Relations and Diplomacy \\ Afe Babalola University, Ado-Ekiti \\ Ekiti State, Nigeria \\ E-mail: adeibjope@gmail.com \\ Bheki Richard Mngomezulu \\ Department of Political Science \\ University of the Western Cape (UWC) \\ Bellville, South Africa \\ E-mail: Kizulu@yahoo.com
}

Received: April 19, 2017

Accepted: March 10, 2018

Published: Dec. 5, 2020

doi:10.5296/iss.v8i2.18067

URL: http://dx.doi.org/10.5296/iss.v8i2.18067

\begin{abstract}
The history of African decolonization discourses in the United Nations (UN) in the 20th century was replete with vested interests under the guise of moral concerns. This interest was occasioned mainly by the prevalence of the Ideological struggles better known as the 'Cold War' between West which the United States led, and the East which was led by the then Soviet Union and allies respectively. Against this background, this paper argues based on the preponderance of archival documents and relevant scholarly resources that the deep-rooted worldwide rivalry for world dominance which ensued between these power blocs after the end of the Second World War in 1945 ushered in a period of politicization of African decolonization issues in the UN from 1960 onwards. The line between egotism and empathy narrowed significantly to the extent that it became too thin to recognize. The findings of this paper show that the Cold War phenomenon significantly
\end{abstract}




\section{Macrothink}

shaped the position taken by member states during the debates on the African colonial problem in the UN. Secondly, we conclude in this paper that from the 1960s, the UN became the battleground between the East and the West each fighting for supremacy.

Keywords: Decolonization, Cold War, Organization of African Unity, Politics, United Nations, United Nations General Assembly, African Union, New Partnership for African Development 


\section{Introduction}

The Cold War shaped the international system in the $20^{\text {th }}$ century so much that it became a leveraging force on African colonial issues and other matters of global interest. It is argued in Sullivan (2005:105), that "At the time of African decolonization, the Cold War was already in the process of being thoroughly globalized. Throughout Africa, decolonization frequently became entangled with East-West conflict..." The Cold War also shaped much of global politics for 45 years so much more that nearly all "...struggles for liberation were viewed through the prism of East-West rivalry..." Against this background, this paper examines the East-West struggles within the context of the politics of African decolonization in the United Nations. The paper seeks to address the following questions:

- Why were the issues of decolonization politicized in the UN?

- What were the roles played by state actors in this regard?

\section{Background to the Politics of Decolonization}

It is important to reflect on key historical events that prepared the stage for the politics of decolonization in the UN. From the 1945-1989 issues of international importance were mostly viewed from the angle of a phenomenon which polarized the global political space the Cold War. As Kay (1970:102) argued, “...the Cold War has for twenty years been the most pervasive force affecting contemporary international relations..." It is within this context that this paper is contextualized.

By the end of the Second World War in in 1945, the international system metamorphosed into a bipolar structure with the emergence of two major superpowers which wielded military and political powers in an antagonistic fashion. The two antagonistic blocs were the United States of America (USA) and the Union of Soviet Socialist Republics (USSR). This situation, suffices to say, was occasioned by the compelling realities at the time. First among these was the defeats inflicted on both Germany and Japan by the Allied forces. Second, was the significant loss of influence by France and China who were both considered as great powers but turned out to be less important than most people had believed. Great Britain, on the other hand, having undergone a gruelling and devastating six years' war, could not muster the strength required of a superpower nation (Baker, 1968).

The post- Second World War period triggered a new dimension in international politics as new political and military camps emerged after the cessation of hostilities by the ideological belligerent blocs. As a result of this, the wartime synergy among the allied powers which ensured considerable global stability collapsed spectacularly as egotism paved way to a deep-rooted competition between the United States and the Soviet Union and their allies respectively. The United States and its western allies felt threatened by the expansionist activities of Soviet bloc and its communist ideology they believed had grave implications for their economic, political and military interests. In Eastern Europe, the Soviet Union sought to exert its influence in the entire region. Having been spurred by the desires for security, it demonstrated that the states of Poland, Czechoslovakia, Hungary, Bulgaria, Rumania, Albania, Yugoslavia, and Finland had governments that were friendly to the USSR. It was 
against this background that communists in these countries, with the aid of the USSR authorities, formed a coalition of governments with the socialists and other parties which showed interests (Baker 1968). The Soviet Union idea of forming a coalition government with these states was strategic for two reasons. First, the Moscow believed that such an arrangement would prevent the West from making ideological incursions into the region.

Second, the Soviet Union also found that a fully integrated communist Eastern Europe could act as a springboard for their global ideological agenda. In other words, the Soviets' plan was to use its sphere of influence as a platform for the spread of communism to other parts of the globe. From the standpoint of the Western world, Eastern Europe under the dominant control of communists portended danger if not contained. As the threat of communist expansion assumed a frightening dimension because the communist had exported their ideology to other parts of the world, this became unsettling to the western bloc. For instance, the Soviet Union had attempted to establish a foothold in the Middle East and the Turkish Straits. In the Middle East, for example, Soviets delayed the withdrawal of its troops from Iran to obtain economic and political concessions from the Iranian government (Baker, 1968).

The Soviets also attempted to bring the Turkish Straits under its ideological influence during the Cold War era regional conflict between the Soviet Union and Turkey. Turkey, a neutral European state throughout most of the Second World War period, came under pressure from the Soviet government which requested that Russian ships be allowed free through the passage the Turkish Straits, which linked the Black Sea to the Mediterranean Sea. According to Baker (1968:7), the Soviets also proposed to "participate with Turkey in the organization of the defense of the Straits." The Turkish government in a swift response rejected the Soviet Union's requests. This action of the Turkish government then, aroused tensions in the region as the Soviets could not swallow the humiliation it suffered as a consequence of the rejection of its application about the Straits. This action later culminated in a show of naval force by the Soviet Union which targeted at forcing its way through Turkey.

The crisis would then serve as a decider in the invocation of the Truman Doctrine by the United States government since Turkey was looking potentially vulnerable to Soviet naval superiority. The Turkish government being worried by the situation was left with no other option to request for the United States and NATO for protection. It was NATO's his development was a triumph for the United States and its allies having added turkey to their In Korea, which was jointly occupied by the American and Soviet forces, negotiations to put in place an independent government failed due to the scheming of the superpowers for influence in the region. The United States and the Soviet Union both demanded that the government of Korea, when constituted, would not fall under the control of each. Also, the collapse of the American sponsored talks in China aimed at settling the differences between the nationalists and Communists in that country brightened the prospects of a Communist triumph, as the situation eventually culminated into the addition of a major state to the Socialist camp.

The intense competition between the Soviet Union and the United States was explained by President John Kennedy of the United States in 1963 who described the acrimonious relations between the East and the West as global competition between the Communist bloc and the 
non-communists. Meredith (2006). Two years into hostilities, the United States leveraged its foreign policy machinery to determine the doctrine of Marx, Lenin, and Stalin. This leverage decision from the American perspective would help formulate a sound foreign policy toward the Soviet Union. Consequently, by March 1947, American foreign policymakers had produced a strategic foreign policy which would build the United States Cold War behavior.

The Cold War policy of the United States was captured by George Kennan as follows: “...the main element of any United States policy toward the Soviet Union must be that of a long-term, patient but firm and vigilant containment of expansive Russian tendencies." (cited in Baker (1968:8) This formed the basis of the United States engagement with the Soviet Union in the Cold War years. While the United States lacked the clout to completely halt the ascendancy of the communist movement, the American policy makers and strategists were however convinced that they could employ their policy of containment effectively which is against their bitter rivals and would thereby force the Soviets to demonstrate a far greater level of moderation and decency in its ideological campaign and expansionist agenda. The American calculation was that this would culminate into a collapse or at least in the immediate time a softening of Soviet Union power. The U.S Cold War policy was initiated and made public in March 1947 by President Truman which subsequently became known as the Truman Doctrine.

In an address to the United States Congress, President Truman stressed the need to provide economic and military assistance to Greece and Turkey following Britain's decision to curtail its assistance to the them. In his speech to the U.S Congress, President Truman said the United States must act promptly to rescue these countries from Soviet Union's incursion. The President said, "The very existence of the Greek state is today threatened by terrorist activities of several thousand-armed men, led by Communists, who defy the Government's authority..." cited in Baker (1968). The Soviet Union also unveiled it Cold War policy. At the Soviet Africanist Coordinating Conference held at the Ethnographical Institute of the Soviet Academy of Sciences in February 1957 in Moscow. By 1961, a well-defined policy toward had emerged. As Alexander Dallin opined, the sole objective of the Soviet policy was to "... Deny Africa to the West, and especially to deprive the United States and its allies of political influence, economic opportunities, and strategic bases in Africa." Cited in Baker (1968:8)

This is instructive given that the realist power theory argues that state actors in the international system are driven primarily by power and national interests which may sometimes be pursued under moral concerns. The question now becomes: how did the Cold War influence the course of African decolonization in the post-1960 decades, especially in the United Nations which became the most powerful platform where the struggle against colonialism was fought with genuine interests by Pro- liberation forces on one side, and the anti-liberation forces on the other side of the divide? This is examined in the following section.

\section{The Colonial Declaration and Politics of Decolonization}

The fifteenth session of the United Nations General Assembly (UNGA) opened on September 20, 1960. The session was attended by the prominent world leaders among whom Nikita 


\section{Mll Macrothink}

Issues in Social Science

ISSN 2329-521X

2020, Vol. 8, No. 2

Khrushchev, the Prime Minister of the USSR. The session was a milestone in the history of African decolonization due to the unprecedented number of African territories that obtained their independence in that single year. The year was also significant in the life of the UN itself as the organization admitted a record sixteen new African countries into its fold. In total, seventeen countries were admitted in that session of which only Cyprus was the non-African country. The newly independent countries were scheduled for admission into the UN before the UNGA meeting.

The unprecedented upsurge in African representation at the UN did not go unnoticed. In fact, as early as the opening day of the fifteenth session of the UN General Assembly meeting the Soviet Union had begun to strategize on how to win their way into the hearts of the leadership of the emerging countries at the expense of their old ideological rival- the United States and its colonialist allies. The Soviet Union believed a hard-anti-colonial would help win the hearts of the newly independent countries. In an era of bitter rivalries, characterized by the arms race and desperate competition for influence throughout the planet, the Soviet Union leadership believed that one of the ways to which they could contain their rivals was to penetrate Africa - not through the traditional pattern of forceful colonization but by tactically aligning themselves with the predicament of Africans many of whom at the time languished under western colonialism.

Historically, the United States never owned a colonial empire in Africa in the same sense as its European colonial powers. Its relation with Africa in the 19th century was with Liberia a West African country which was established by Americans for Americans. The American Colonization Society which was established by an Act of Congress in 1816, was empowered to facilitate a program of sending freed slaves of African descent back to the continent due to the growing fears by a section of white Americans that people of African descent would become too numerous if the government failed to take action that would reduce their numerical strength.

However, the United States had many of its Cold War allies having colonial possessions in Africa. Britain, France, Portugal, Netherlands, Spain, Belgium, and Germany at some point all had colonial territories which they administered in Africa. These countries were staunch allies of the United States in the Cold War years a situation that tied America's hands as far as the struggle against colonialism in Africa was concerned. America thus became an ordinary anti-colonial country in rhetoric and a tactical supporter of colonialism in its actions. As the UNGA meeting was about to get under way, Khrushchev's delegation having arrived very early on the opening day of the convene was full of confidence that his country would tower above its arch-rival the United States in every respects. He uttered a statement that showed the deep-rooted rivalries between the two Superpowers. This statement however subsequently influenced proceedings on the floor of the General Assembly (GA) throughout the seating. According to Boris Piadyshev, the Soviet Union Leader had on September 20, the opening day of the sessions boasted that his country would outshine the United States in every human endeavour as Khrushchev wondered what time it could be in Moscow. As it happened, it was about $3 \mathrm{pm}$. The Soviet leader then said, "You see Mother Nature itself put Russia ahead of America in time. We will get ahead of America in all other respects as well." (Note 1) 


\section{Mll Macrothink}

Issues in Social Science

ISSN 2329-521X

2020, Vol. 8, No. 2

The intensity of the rivalry between the Soviet Union and the United States could not have been portrayed better by Mr Khrushchev who afterward became a "volcano," waiting to "erupt." As Piadyshev puts it, Khrushchev was "boiling over, looking for a vent." (Note 2) The Soviet Union's leader finally had his time to speak on the floor of the United Nations General Assembly UNGA on September 23, 1960, following the Ghanaian President Kwame Nkrumah's address at the morning session. The Ghanaian leader's presentation was greeted with tremendous applause which earned him handshake from Khrushchev who was delighted with the forcefulness of the Ghanaian leader's address.

As the head of the Soviet Union delegation the responsibility was on Khrushchev to express his country's disapproval of Western colonialism. Thus, on 23 September 1960, the Soviet Union Leader delivered a speech which aroused tensions in the UN for the better part of the fifteenth session. Khrushchev began his remarks thus: "The Soviet government believes that the time has come to raise the question of a complete and final abolition of colonial rule, putting an end to this disgrace, barbarity and savagery." (Note 3) His opening remarks received a huge applause not from the Western blocs but from the representatives of the newly independent countries including those that had just joined the UN a few days before. The Soviet Union leader took time to remind the UNGA gathering that his country had the moral uprightness to denounce and call for the elimination of colonialism when he quickly made reference to the "spectacular achievements," (Note 4) which had been recorded by Russia's former Central Asian colonies since 1926. Premier Khrushchev claimed that countries formerly under Russian rule had grown tremendously in agriculture and technology terms. His aim in this regard was to inform the UNGA delegates present at the session that the country practiced what it preached. This argument was strategic in the sense that it sought to provide a moral basis for the Soviet Union's actions at the session. It was simply a case of promoting national interests under the pretext of morality or better put moral concerns.

Worthy of note is the fact that a vast number of independent countries which joined the UN in 1960 had a profound impact on the UN machinery. Regarding the alteration, it generated in the '...voting balance in the Assembly...' (Kay, 1970:151) In fact, from 1945 to 1960, over one-third of the Assembly was composed of nations which had attained their political independence in the post-1945 era (Kay 1970). This reality thus became an instrument of leverage for the Soviet bloc during the 1960 session. In addition to this, there were other issues of global dimension that attracted widespread indignation across Africa and the world which gave African problems a special attention in the UN in the years which followed beginning from 1960. These issues were the Sharpeville incident in South-Africa which led to the killing of 69 unarmed protesters by the apartheid police in March 1960 and the Congolese crisis which was triggered by the Cold War animosity and its divisive consequences which later claimed the life of the country's first post-independence political leader in the person of Patrice Lumumba.

All these events contributed towards the emergence of the Soviet Union's anti-colonial initiative. These were the political contexts in which Khrushchev having earlier made his position known on the colonial question later in the course of his " 2 hours and 20 minutes speech", formally made a request to the Assembly that an additional item, which was titled a 


\section{MInstitute Macrothink $^{m}$}

"declaration on the granting of independence to colonial countries and peoples," (Note 5) be included on the agenda of the seating. The draft which followed the request was extremely radical in content and tone. Even the newly independent countries could not have presented something more radical than the one presented by the Soviet Union. The Soviet anti-colonial draft proclaimed that in the colonial territories controlled by European allies of the United States, "the swish of the overseer's lash is heard; their heads fall under the executioner's axe." (Note 6) The Soviet Union's anti-colonial onslaught did not end there; it went on to demand an immediate abolition of colonial rule. The delegation believed this would dry up the ocean of injustices which the colonialist had thrown Africa and its peoples into.

Therefore, to save the colonized people the Soviet Union declaration proceeded with the proclamation that all countries under colonial rule "must be granted complete independence forthwith." (Note 7) In addition to this, the Soviet Union also demanded that all foreign colonial plantations be demolished. The General Committee on September 28, 1960, sequel to the Soviet Union declaration recommended that the item be included on the agenda of the sessions for a debate on the draft. With this success, the Soviet Union secured a major victory in its anti-colonial initiative. In accordance with the tradition of the Assembly, the General Committee recommended that the Soviet Union item be passed first to the Political and Security Committee for its preliminary consideration.

On October 10, 1960, the Assembly sequel to the General Committee's recommendation of September 28, 1960, approved that the Soviet Union's item be placed on the agenda for debate. However, a paranoid Soviet Union delegation acted quickly to thwart any move by the west to kill its anti-colonial initiative with a proposal urging the Assembly to deliberate on the issue at the plenary session and not follow the traditional procedure put in place to deliberate on issues.

The Soviet Union's fears in this regard can be attributed to two key factors: first, was the fact that the Soviet Union delegation at the fifteen session was aware of the potency of the plenary session of the General Assembly to deliver on a keen subject like colonialism because of its wide coverage by the world media. The fact that proceedings at the session would be disseminated across the globe prompted the Soviet Union to insist on having its draft proposal considered in a debate on the floor of the Assembly. The second factor was due to the voluminous nature of the fifteenth session agenda which had close to a century of issues scheduled for discussion by the Assembly. The Soviet Union due to the existing rivalry between them and the West were firmly convinced that the West, being the architects of the colonial crisis and the colonial system would scheme to bury its anti-colonial initiative under the guise of the tight agenda of the session. The Soviet Union leader Khrushchev thus made an appeal to the General Assembly (GA) session that the issue be allowed for discussion in plenary. He stated as follows:

The USSR delegation has submitted this question for consideration by the most representative organ of the United Nations, the General Assembly in plenary meeting. It is quite clearly essential to hold the debate in this forum and no other, and at the highest level with the participation of the Heads of Government. Discussion of the 
problem of elimination of the colonial system directly in the plenary with the participation of the Heads of Government and the Ministers for Foreign Affairs of Member States of the United Nations will invest the debate with the most authoritative character and secure the most favorable conditions for the successful solution of the problem within the framework of the United Nations. Kay (1970:152).

Khrushchev's appeal was received by members of the General Assembly present at the session with mixed reactions. The western stance and those of the majority of Latin American countries - many of whom were ex-colonies of western colonial powers such as Portugal, Spain, and France were intriguing. They were of the opinion that regardless of the merits of Soviet Union argument, the procedural order for the consideration of issues at the General Assembly should not be altered, adding that the procedural breach which Khrushchev advocated would in the long-run lead into propaganda warfare between the two major blocs given the tension - laden struggles between them at the time. Britain, the colonial power with the largest existing colonial territories at the time repudiated the Soviet Union request that the issue of colonialism be tabled for consideration at the plenary. As arguments for and against the presentation of the Soviet Union anti-colonial initiative at the plenary raged, the Soviet Union request to have the issue of colonialism discussed by the General Assembly plenary got a major boost from the newly emergent African countries.

These groups of countries having emerged recently from the shackles of colonialism were understandably more desirous of stamping out colonialism from their continent having experienced the phenomenon for decades. Thus, the Soviet Union's request to have its anti-colonial declaration debated on the floor of the General Assembly was enthusiastically welcomed by the new countries. Among the most ardent states was Nigeria who threw its weight behind the Soviet Union proposal despite being seen as relatively pro-Western. Kay (1970) With the support of the African contingent at the plenary, it was then the turn of the new countries from Asia to make their contribution and take a position on the request put forward by Khrushchev. The position of the Asian countries at the plenary was subsequently made known on the issue. To the Asian group, both the First Committee and the plenary sessions of the General Assembly are both relevant in the procedural consideration of issues at the United Nations.

Therefore, they resolved that they would align themselves with the Soviet Union request in deference and solidarity with their new comrades from Africa and not by its argument which was considered unconvincing. Zulfikar Ali Bhutto of Pakistan who spoke on behalf of the Asian group at the session said:

We feel that the First Committee is as important a forum as the Assembly in plenary session. However, the consensus, and especially those of our new comrades who have recently joined us from Africa, seems to be that this issue is discussed here in plenary and in recognition of their wishes, we shall support the Soviet amendment that this issue, this very vital issue, be discussed in plenary. Kay (1970:152)

Having provided the rationale for its position, the Asian group joined forces with the Soviet Union bloc and the new African states in the quest to have the anti-colonial declaration 
discussed at the plenary. As noted above, many of the Latin American countries and the West had before this time opposed the Soviet Union request on the basis that it could result in a propaganda battle between the East and West. Thus, the General Assembly was set for the first round of debate which was a prelude to the voting which followed.

The question then becomes: what were the factors that forced the United States led western bloc to support the request put forward by the Soviet Union bloc? The answer to this question is deeply entrenched in the reality of the Cold War aims and the objectives of the rival blocs. It is important to observe that the Cold War had economic, political and ideological motives which both sides pursued with varying degree of desperation and tactics. From the Soviet Union standpoint, for instance, its anti-colonial behaviour was in tandem with the bloc's grand plan to prevent it rivals from having a foothold on the African continent. As Baker noted, "In the short run, Soviet leadership has encouraged the African states to pursue... and cultivate increasingly close economic, political, and cultural ties with the Soviet bloc" Baker (1968:32) The United States - led Western bloc on the other hand was gripped with the fear of losing the newly independent countries -ideologically to their Eastern rivals. Consequently, there was need to reverse the prior decision on the issue due to the prevailing realities at the session and in the world, which portended that they would be on the losing side if voting were to take place on the subject at that stage. Following days of debate fireworks on the consideration of the Soviet Union request that the anti-colonial declaration be considered in plenary, the General Assembly finally on October 13, 1960, adopted by acclamation that the issue be discussed in the plenary. Khrushchev after that explained the philosophical underpinnings of his country's draft declaration on colonialism thus:

I very much like the words of August Babel, the social - democrat and leader of the German workers, who said, more or less, this: if the bourgeoisie praises you, Babel thinks, in that case, what a stupid thing you must have done. If the bourgeoisie reviles you, it means that you are truly serving the working class, the proletariat! If the colonialists now revile me, I am proud of it, because it means that I am truly serving the peoples who are struggling for their independence, for their freedom (Note 8).

Khrushchev's submission was a direct verbal missile against the Western colonialists who were portrayed as antagonists of freedom for the colonized African peoples. The Soviet Union strategy was simply to incite the new countries against the Western colonial powers in order to establish itself as the leading anti-colonial power and a friend of the colonized peoples of the world. The Soviet Union agenda was a subtle attempt to prepare grounds for the recruit of the newly independent African countries into Eastern bloc. The Soviet Union draft raised some fundamental questions, for instance, it sought to know:

For what purposes do those who refuse to renounce colonial rule wage murderous war against peoples? Why are the freedom-loving aspirations of the enslaved peoples suppressed? Sometimes it is said that this is done in the interest of the "civilization" of the less developed countries to prepare them for self-government. But this is a lie given the guise of truth (Note 9 ).

It is instructive from the above that the Soviet Union draft was anti-colonial. The draft further 
espoused the economic motivations of the colonizers thus:

The primary object of the colonial regime is, in fact, to secure enormous profits for big foreign monopolies, which have seized the key economic positions in the colonies and to extort their wealth by every possible means. Therefore, the entire economy of a colony is one of exploitation (Note 10).

The draft proclaimed that:

(a) All colonial countries and Trust and Non-Self-Governing Territories must be granted forthwith complete independence and freedom to build their national States by the freely expressed will and desire of their peoples. The colonial system and colonial administration in all their forms must be completely abolished to offer the people of the territories concerned an opportunity to determine their destiny and form of government.

(b) Similarly, all strongholds of colonialism in forms of possessions and leased areas in the territory of other States must be eliminated.

(c) The Governments of all countries are urged to observe strictly and steadfastly the provisions of the United Nations Charter and of this Declaration concerning the equality and respect for the sovereign rights and territorial integrity of all states without exception, allowing no manifestation of colonialism or any special rights or advantages for some States to the detriment of other States (Note 11).

With the decision taken in favour of the Soviet Union that its draft be debated in the plenary, the various groupings, having studied the trend at the Assembly, began to hold talks on whether to support the draft or not. The Afro-Asian group which at the time included all the new countries in the United Nations with the exception of the state of Israel took the lead when they came up with a consensus arrangement which favoured formulating a draft of their own that would be in tune with the realities of the time and not just be swayed by that of the Eastern bloc which many of the North Africans and Arab states considered to be intemperate in its language and too extreme in its demands that all leased areas and bases be removed from foreign soil. Kay (1970).

This was quite understandable given that the East delegation set out to achieve a Cold War objective. The only way in which they could get this done was by attacking the colonial system and its controllers in a vicious fashion. The Afro-Asians were also conscious of the current realities at that time and given the extreme contents of the Soviet Union "demands," it was abundantly clear that the draft would not get the required number of votes needed for its adoption by the General Assembly. The general belief among the Afro-Asian countries was that Soviet Union sponsorship of the draft could result in a "Cold War" vote in the plenary given the Latin Americans support for the western colonial powers. The Latin American countries were of the opinion that colonialism wasn't bad in its entirety as Soviet Union portrayed it. According to the Latin group, colonialism had it merits. Consequently, a vote on the draft initiated by the Soviet Union would have suffered a defeat (Note 12). 


\section{Macrothink}

The Afro-Asians swung into action the moment they formulated their draft. The fifteenth session had a strong Afro-Asian membership presence of 45 countries, 33 of which were new countries in the world body given that they had obtained their independence in the post-1945 era (Kay 1970). In achieving their target, the Afro-Asian delegation quickly set up a committee that would prepare a draft which would be representative of the group's views. To this end, a six-member drafting committee which comprised Nigeria, India, Indonesia, Guinea, Iran, and Senegal was instituted and saddled with the task. Worthy of note is the fact that four of the members of the drafting committee - Nigeria, Indonesia, Senegal, and Guinea were new members - with Nigeria being the newest member.

In the case of Nigeria, the country's participation in the drafting committee was motivated by its desire to play a leading role in the struggle against colonialism in Africa. The country's involvement in that committee marked the beginning of its political involvement in the protracted anti-colonial battle. Having been saddled with the assignment, the Afro-Asian group drew up a timetable for itself indicating that it would commence work towards the end of October 1960 beginning with the consideration of the two proposed drafts which it had received from the Guinean and Iranian delegations. These drafts reflected two extremes within the Afro-Asian group. That of Iran was a temperate anti-colonial declaration in the sense that it was devoid of any element of radicalism in dealing with the colonial problem. Unlike the Soviet Union version, the Iranian draft was silent on what should be the appropriate deadline for the ending of colonial rule. It also avoided making the issues personal in the manner that the Soviet Union did.

The Guinean proposal, on the other hand, was much closer to that of the Soviet. It proposed that there should be an immediate end to colonialism. Proposals were also received by the committee from other member countries of the Afro-Asian group like the Indian and Indonesian delegations. The drafting committee in an attempt to ensure that an acceptable outcome which would integrate the views of its membership in the final report is presented jettisoned the voting option for extensive discussion and consensus arrangement in the preparation of its report. On November 2, after series of deliberations and consultations by the drafting committee, a provisional draft was prepared for consideration by a larger working group before the final presentation to the Afro-Asian group for adoption.

The provisional text was altered after intensive scrutiny by the working group. All elements of radicalism like those contained in the Soviet Union's draft were removed. The temperance nature of the draft was explained by Iran's delegate Mr.Vakil thus:

There is no doubt, for example, that many of the co-sponsors of this draft declaration who have suffered greatly from the ravages of colonialism would have preferred a more expressive text, including clauses condemning colonialism in its most culpable aspects. However, to rally all currents of opinion in the Assembly in favour of a text acceptable to all the members of the United Nations, they have, in a spirit of conciliation, accepted certain phrases of a much more moderate nature (Note 13).

By its temperate nature, the Afro-Asian draft was entirely different from that of the Soviet Union's in content. While the Soviet Union's draft was strictly anti-colonial and viciously 
anti-western, the Afro-Asian version distanced itself from such. The Afro-Asian groups in the supreme quest to get the UN General Assembly pass their anti-colonial resolution was cautious in the choice of words in the making of what later became the final draft of the group. For instance, while the Soviet Union draft used the word "demands" in its draft, the Afro-Asians chose the word "declares." Other notable areas of comparison in both drafts included the Soviet Union demand that all colonial territories "be granted complete independence and freedom forthwith," (Note 14) and the Afro-Asian group's call for "immediate steps," (Note 15) be taken to decolonize the colonies, which implied that a gradualist approach should suffice to achieve decolonization. The sharp difference in both drafts wasn't accidental. It was conditioned by a combination of ideological animosity on the one hand, and realism on the other. The Afro-Asian draft was finally adopted and sponsored by 43 member countries in the UN toward the end of November 1960. The stage was then set for the eagerly anticipated debate on both drafts which was scheduled to commence on November 28, 1960.

Before the start of the discussions on the various drafts, the West, having been at the receiving end of acidic criticism from the Soviet Union bloc since the opening week of the fifteenth session for the alleged ill-manner in which the colonial situation was being handled, responded by launching an attack against the Soviet Union's domination of Eastern Europe and its suppression of nationalist agitations for independence in the region. The British delegate to the session, Mr. Ormsby Gore hit back at the Soviet Union's anti-colonial declaration thus:

The representative of the Soviet Union appears to wish to use this debate simply as another occasion for vilifying my country and other Administering Powers and for carrying the Cold War into Africa... I must warn him that if I chose to follow suit, I would have much better ammunition than he has. Since 1939, some 500 million people, formerly under British rule, have achieved freedom and independence, and their representatives sit here. In that same period, the whole or part of six countries, with a population of 22 million, has been forcibly incorporated into the Soviet Union; they include the world's three newest colonies: Lithuania, Estonia, and Latvia... Countless efforts have been made by national movements in countries under Russia control to gain independence. All have been suppressed. In Central Asia, we have seen examples of colonial policy, which as Mr. Khrushchev himself told us at great length earlier in the session \{869th meeting\}, has in material terms been an outstanding success. He did not tell of the mass deportations of populations and the ruthless suppression of nationalities which went with it. I shall not harrow the feeling of this Assembly by reciting the whole grisly catalogue; one or two examples must suffice... (Note 16)

The above statement is illuminating in many ways: First, it showed that the Cold War indeed a leveraging force on the issue of colonialism. Second, the response was a diversionary ploy by the Western Colonial powers on whose behalf the British delegate spoke to divert attention from the radical stance of the Soviet Union. The British delegate sought to turn the tide against what they considered as an immoderate and unrealistic draft which was put forward. 
Third, Mr. Gore's speech also indicates that the Soviet bloc had also benefited from the colonial enterprise like their rival. It was therefore, the pursuit of national interests under the guise of moral concern.

From the British perspective, the tactic was simply to galvanize the newly admitted countries (the Afro-Asians) against the Soviet Union system of colonialism which was painted as being more suppressive, oppressive and averse to the yearnings of the peoples under its control for independence. This sole aim of this strategy was to rubbish its draft resolution on colonialism and also to restrain the Soviet Union bloc from further attacks against Western colonial interests. The British action later backfired as the new countries especially those from Africa deplored the attempt to trivialize the colonial problem through what was described as "Cold War Propaganda" (Note 17). The new countries expressed their dissatisfaction at the attempt by the East and West to use the colonial situation to score cheap political points in the Cold War contest.

In an effort to appease the new disgruntled countries, the West immediately discontinued its attack on Soviet Union's colonialism and instead focused on showcasing the achievements which had been recorded in the former Western colonies. The New Zealand delegate at the session echoed the sentiments of the British delegate Mr. Gore who spoke earlier. He argued:

It is a fact worth recalling that the States which have borne the heaviest responsibilities for the administration of Trust and Non-Self-Governing Territories were among the founding Members of this Organization and that they freely and voluntarily assumed the obligations which the charter created. Their record of performance is symbolized by the presence among us of the representatives of many new states, which have been brought to independence by the United Kingdom, France, and other countries (Note 18).

The above sentiment was premised on the fact that several countries which were formerly under Western control had since obtained their independence consequently Britain and other colonial were not against liberation struggles. The West got support from its former colonies in Latin America who also appealed to the new countries to reflect on the positive aspects of colonialism. However, both the West and the Latin Americans failed in their efforts to convince the new countries in the Assembly on the need to acknowledge the positives of colonialism. The Moroccan delegation disagreed with the sentiments expressed by the British, Latin American, and New Zealand delegations that colonialism had its positives. It insisted that it was nothing short of exploitation, chaos, and destabilization of an existing order. The delegation averred:

The history of colonial conquests, far from being a peak achievement, confronts us with quite different realities. It is nothing other than a stormy succession of wars and expeditions waged by Powers intoxicated by their economic and military potential, seeking to gain strategic positions and hankering for wealth and prestige. The struggles for power between these opposing powers... and their intrigues to partition whole continents reflects little credit on the Powers involved and are certainly not a glorious page in the history of humankind (Note 19). 
The above position was supported by the Malian delegation. It said:

The delegations which speak in this Assembly of their colonial experience or proclaim the benefits of colonialism can unfortunately only speak of the empire of their Father's Day; they talk of it as a heritage. If their countries were colonized at some time in history, they know it from history books. Therein lies the fundamental differences between those delegations and ours, who have personal experience of colonial rule. Our knowledge is not based on hearsay or on what we learned in school; we were for decades the living embodiment of that system. Ours was a generation which, on coming age, did not have the right to vote in its country (Note 20).

The United States on its part aligned itself with the position of the British and the Latin American countries with the preference for a draft which would accommodate the positive roles played by the colonial powers in the colonies and a viable framework that would prepare the colonial subjects and territories for independence. In other words, the United States just like its allies was not favourably disposed to the draft version presented by the Soviet Union due to its malicious and vindictive textual nature.

During the debates on the draft proposals, the Afro-Asian countries agreed unanimously before going into voting on the need to rapidly end colonial rule. This action was reflected in their draft resolution even though there was a slight division among its membership about what should be the appropriate time for ending colonialism. Nevertheless, the prevailing opinion among the Afro-Asians was that regardless of the time-frame, the group would rally round its draft for possible adoption by the UN General Assembly because the text was non-controversial compared to the Soviet Union's version. In a bid to garner support for its draft, the Afro-Asians appealed to their Western and Latin American counterparts to give support to their draft proposal in order to prevent the Soviet Union draft from sailing through voting. At this point, the paramount objective of the Afro-Asians was to get the General Assembly to vote, pass and adopt its draft resolution at the plenary. It is important to also note that the Afro-Asian decision to appeal for support did not in any way compromise the content of their draft given the fact that had prior issues with these delegations. The group's plan was simply to secure the passage and adoption of their draft by the General Assembly as the official position of the UN on colonialism.

Despite the unpopular draft of the Soviet Union, they remained confident of getting their proposal voted for and adopted by the General Assembly. However, the Soviet Union representative Mr. Zorin lauded "the desire shown by the overwhelming majority of African and Asian delegations that measures should be taken...to advance the realization of that lofty goal-the complete liberation of the peoples of all colonies and dependent colonies." (Note 21) At this stage, with voting only a matter of days away, it remained obscured whether the Soviet Union would withdraw its draft to pave way for the Afro-Asian version. The Afro-Asian draft prior to voting received support from the Scandinavian countries and the Netherlands. Britain and the United States both gave support to the Afro-Asian draft before the commencement of voting. 


\section{Mll Macrothink}

The Latin Americans on their part following the appeal for support by the Afro-Asian group expressed their resolve to support the agitations of the Afro-Asian group despite being initially critical of the group for its non-admittance of the beneficial aspects of colonialism. The Latin American delegations however declared that they were not against the call for the termination of colonialism but were only interested in and concerned about the process of achieving this objective. They claimed that it was "no longer a question of discussing whether or not colonialism must be brought to an end, but of determining the methods, time limits, and procedures by which the process of liquidation is to be effected." (Note 22) There was a late twist in the build-up to the voting on the two proposed drafts. This happened on December 13, 1960, the day preceding the commencement of voting. The Soviet Union in a desperate last - minute scheming, attempted to tacitly give its draft and that of the Afro-Asian group a sense of uniformity to create the impression that both are on the same trajectory of views. Mr. Zorin of the Soviet Union had argued that both drafts had "a common platform and identical views on some vital questions." (Note 23)

The Soviet Union amended draft suggested the end of 1961 as a target date for the elimination of all forms of colonialism. The Afro-Asian version, on the other hand, was silent on what should be the exact date for bringing colonialism to an end. The drafters of the proposal preferred to have this question and the implementation of the resolution that ensued reflected on the agenda of the sixteenth session. After weeks of intense debate fireworks, accusations and counter- accusations rival blocs, the General Assembly got down to the business of voting on the lingering and contentious question of colonialism. On December 14, 1960, voting on the two drafts began. The introductory paragraphs of the Soviet Union which called for immediate granting of independence to the colonial countries and peoples and the removal of existing foreign bases in colonies were the first items to be voted upon. This call was defeated narrowly with 32 voting in favour, 35 against, and 30 abstentions (Note 24). The voting trajectory on this particular item is reflective of the dichotomy which existed between the Eastern and Western blocs.

For instance, while all the communist states totaling eleven except China voted in favour of this item, the reverse was the case with respect to the voting response of the Western, Latin American and few Scandinavian countries. Of particular interest is the fact that the United States and its colonialist allies voted against this item with France, Belgium, United Kingdom, Spain, Portugal and Netherlands all voting in rejection. These colonial powers were joined by most of their ex-colonies and their traditional friends. At this point, it was quite clear that the West was in the ascendancy having won the first round of vote against the Soviet Union's draft. With the first round of voting completed, the UN General Assembly proceeded to vote on other controversial and highly contentious issues contained in the Soviet Union draft. The item which was considered was the condemnation of colonialism and its architect the Western colonial powers. This particular item was massively voted against with 25 voting in favour, 43 against, and 29 abstentions (Note 25). Unlike the prior voting, the outcome of the second vote presented a clearer picture of the impending comprehensive defeat which awaited the Soviet Union sponsored anti-colonial draft. As observed the prime objective of the Afro-Asian group was to have an independent anti-colonial framework which would be 
devoid of any Cold War sentiments. The results from the voting showed that some radical countries in the Afro-Asian group of African extraction like Ghana and Guinea voted in favour of the Soviet Union draft resolution, with few others following in that direction. Many African countries also abstained. The voting pattern of Latin American and Western countries remained unchanged. Again, all the colonial powers voted against the Soviet Union draft for the second time. The communist states, except China, also maintained their voting pattern in the prior order. The turn of events showed that the Cold War shaped the trajectory of issues on the colonial situation at the plenary. The third item to be voted upon was the Soviet Union's amendments to the Afro-Asian draft which was submitted before the start of voting. The Ghanaian delegate at the session Mr. Quaison-Sackey appealed to the Soviet Union to withdraw its late amendment especially the one who proposed a 1961 date as the terminal date for bringing colonialism to an end. Unfortunately, the Ghanaian delegation's efforts to get the country's representative to do so proved abortive as the Soviet Union delegate Mr. Zorin insisted on having the item voted upon because according to him, "the voting should disclose the position of all countries and reveal who is interested in the speedy elimination of the colonial system" (Note 26).

At this juncture, it is important to state that the Soviet Union's action vis-à-vis its reluctance to withdraw its amendments to the Afro-Asian draft was as a result of its desire to seek redemption having suffered successive defeats. The country's representatives at the session realized that the only way they could still maintain relevance and influence was to insist on having colonialism and its clear consequences abolished by 1961. In doing so, the Soviet Union believed that they could secure the overwhelming support of the Afro-Asian group who are desirous of freedom. Following the refusal of the Soviet Union delegation to withdraw its amendment, the General Assembly proceeded to vote on the amendment which proposed the year 1961 as the end date of colonialism.

This amendment was again defeated by 29 in favour, 47 against and with 22 abstentions. The second amendment to the Soviet Union draft which requested that the question of the implementation of the anti - colonial declaration be placed on the agenda of the next sixteenth session was afterwards voted on. This garnered a simple majority but could not secure passage due to the absence of a required two-thirds majority with 41 voting in favour, 35 against, and 22 abstentions (Note 27). On the conclusion of voting on all the items in the draft resolution, Soviet Union could only secure partial victory because the simple major vote was insufficient to guarantee passage of the resolution. Also worthy of note is the fact that the United States and its Western colonialist allies voted against all the items contained in the Soviet Union's draft resolution on colonialism. Even the well-reasoned amendment suggesting that the implementation of the declaration be inserted into the agenda of the sixteenth session could still not suffice to convince the United States and its allies to vote in favour of the resolution.

The question then becomes: what could have been responsible for the United States and its ally's decision to vote against this item having earlier dismissed the accusations levelled against them by the Soviet Union that the West were unwilling to dissolve their overseas colonial empires to pave the way for independence? The answer to this question lies in the 
fact that the Western colonial powers could not have given support to a resolution sponsored by their arch-rival the Soviet Union due to the Cold War crisis which had put enmity between them. The fact that a proposal of that kind is put forward by the Soviet Union rubbishes whatever positive intentions it may have. Consequently, the Western colonial powers' decision to vote against the Soviet Union's draft despite their claim that they were favourably disposed to decolonizing Africa was more of a rhetorical commitment than demonstrable commitment as events which followed suggest.

After the routing of the Soviet Union's draft resolution, the UN General Assembly turned its attention to the Afro-Asian draft which was the remaining anti-colonial proposal left for consideration by delegates at the session. When the draft was put to the vote, 89 voted in favour, none against, and with only nine abstentions. The Afro-Asian draft then became the United Nations General Assembly resolution 1514 (XV) titled, a "Declaration on the Granting of Independence to Colonial Countries and Peoples." (Note 28) The Western colonialists this time around preferred to abstain than to vote either in favour or against the Afro-Asian resolution because of the fears that the Soviet Union would take advantage of their action to portray them as reactionaries of freedom. For instance, if the West had voted in favour, the Soviet Union would have undoubtedly claimed glory for initiating a colonial resolution that eventually brought down the pillars of Western colonialism.

The Soviet Union then would have used the feat to win over the newly independent countries in Africa into its ideological camp. Second, a vote against this popular Afro-Asian resolution by the West would have been catastrophic for the colonial powers given the fact that Moscow made communist ideology posed a serious threat to their political and economic interests on the African continent. Consequently, the West was left with no other option than to abstain. The colonial powers that abstained included: France, United Kingdom, Spain, Belgium, Portugal, Union of South Africa, (the apartheid enclave) and the United States - the leader of the Western bloc. Others were: Australia and the Dominican Republic. From the foregoing, it is evident that it was not just the temperance of those draft resolutions per se that was the uttermost concerns of the United States and the colonizing powers, but the desire to maintain the status-quo in their respective colonies.

As the fifteenth sessions of the UNGA meeting came to a close, interest groups within the Assembly were confident that the next session scheduled for 1961 offered another opportunity to advance their country's national interests. From the Soviet Union standpoint, the sixteenth session presented the country with the prospect to re-launch itself into reckoning having endured successive defeats on its draft resolution and also suffered tremendous setbacks. The Western bloc, on the other hand, were confident of keeping the momentum going in their favour having contributed heavily towards the defeats of the Soviet Union draft resolution. Other groups in the Assembly such as the Latin America group and the Afro-Asians maintained their positions on the colonial situation going into the next session.

\section{An Attempt to Implement the UN Colonial Declaration}

For the second successive year, a resilient Soviet Union took the lead in denouncing Western colonialism at the sixteenth UN General Assembly session. On 28 August 1961, the country's 


\section{Mll Macrothink}

delegation requested that the General Assembly put on its agenda an item entitled "The Situation about the Implementation of the Declaration on the Granting of Independence to Colonial Countries and Peoples." (Note 29) This request according to the Soviet Union delegation was necessitated by the discomforting reality that the colonial declaration had remained unimplemented since it was adopted at the fifteenth session. Consequently, they called for practical measures which would lead to the enforcement of the UN General Assembly declaration on colonialism and a target date to bring this about. In addition to this, the Soviet Union also called on the U.N to put in place machinery that would be saddled with the responsibility of ensuring the supervision and control of the implementation of the declaration.

The clouds of the Cold War which pervaded proceedings at the fifteenth session resurfaced at the sixteenth session when the United States and its colonialist allies for the second year running came under verbal attack from the Soviet Union, this time for failing to respond actively to the declaration as expected. A strongly worded memorandum which followed its initial request condemned the West for continuing with a "policy of terror and repression" in their colonies (Note 30). The United States was singled out for attack with accusations that the country was using the instrumentality of the North Atlantic Treaty Organization (NATO), the Southeast Asia Organization, and the Central Treaty Organization (SAOCTO) to preserve the interests of its European colonial allies thereby frustrating the implementation of the UN General Assembly resolutions on colonialism. The Soviet Union soon after submitted a draft to the Assembly on October 9, 1961. The draft called for "the immediate implementation" of the UN General Assembly colonial resolution of December 1960 and equally proposed a terminal date for achieving this goal when it forcefully declared, "that the final and unconditional liquidation of colonialism in all its forms and manifestations must be implemented not later than the end of 1962." (Note 31)

Moreover, the Soviet Union sponsored draft also urged the UN General Assembly to prevail on the administering powers to withdraw their foreign military, political and economic presence from the dependent territories and put in place as a matter of urgency "a special committee commission to conduct a full and complete inquiry into the situation with respect to the implementation of the Declaration on the granting of independence to colonial countries and peoples and the measure for carrying it into effect." (Note 32) Afterwards, the leader of the Nigerian delegation to the session and the Permanent Representative to the UN Mr Ngileruma proposed 1st December 1970 as the target date for the termination of colonial rule. This proposal was later adopted by the Assembly given its viability. (Baker, 1968).

On Soviet Union's call that prompt actions should be taken to implement the colonial declaration, the Nigerian delegation, acting as the mouthpiece of the Afro-Asian group, called for caution in Moscow's approach to the issue, “...my delegation feels compelled to add that we, and by "we" I mean the Africans and Asians who have worn the shoe of colonialism, know best how and when it pinches (Note 33). However, the Nigerian delegation was thankful to the Soviet Union for its efforts toward finding a lasting solution to the colonial problem. It stated: "My delegation must express its appreciation to the delegation of the Soviet Union for the interest and initiative which they manifested in the problem of the 
speedy liquidation of the remnants of colonialism." (Note 34)

The Afro-Asian group was subsequently confronted with a trend which was reminiscent of the UN General Assembly's fifteenth session politicization of the colonial situation. The group was discerning this time as they quickly instituted a process of crafting an independent draft resolution which would lead to the implementation of the 1960 declaration on colonialism. In the course of preparing this draft, the Afro-Asians engaged in extensive consultations within the Assembly to accommodate the views of other interest groups at the session. This was to ensure that they secured a considerable number of votes when the draft was presented for voting and subsequent adoption in the session. The overriding objective of this group, therefore, was to have a resolution which would appeal to various groups in the Assembly - the United States and its colonial allies included. In other words, the Afro-Asians this time around preferred to act as a balancing force in the Assembly. The group's thinking on this strategy was explained by Mr. Subandrio of Indonesia. He said:

We believe, first of all, that this draft the result of extensive consultations and discussions - reflects a spirit of giving and take and, in this respect, represents the widest possible area of agreement that can be obtained in this Assembly. For example, although my delegation believes it possible and desirable to end colonialism in two years...the authors of this draft resolution have taken into consideration the fact that a difference of opinion exists on this subject, not only within the African-Asian group itself but in this Assembly as a whole (Note 35).

The draft that later emerged from the consultations was sponsored by 38 Afro-Asian states. The initiators of the draft having reflected on the colonial crisis were of the view that finding a solution to the problem could begin by the setting up of a special committee which would be vested with powers to suggest and recommend the realizable and appropriate ways of implementing the declaration. However, the signatories to the draft did not hesitate to call on the administering powers of colonial territories to ensure compliance with the declaration. Referencing the UN General Assembly 1960 resolution 1514 (XV) on colonialism, the draft asked the States concerned "to take action without further delay with a view to the faithful application and implementation of the declaration." (Note 36) It concluded by also proposing the establishment of a 17-member state Special Committee to be nominated by the President of the General Assembly. The Special Committee was expected "to make suggestions and recommendations on the progress and extent of the implementation of the declaration." (Note 37)

Interestingly, not many people at the sixteenth session of the UN General Assembly would have predicted a quick shift in the United States' stance on the 1960 UN General Assembly Colonial Declaration following the announcement by the United States that it would help advance the purposes of that declaration. This change of policy was summed up briefly by the United States representative Mr. Jonathan Bingham who notified the Assembly thus:

... My country has associated itself with the principle of that historic Declaration. We shall be happy if, by our participation in this and future debates, as well as by our actions, both within and outside the United Nations, we can help to advance its great 
purposes (Note 38).

It is important to examine the factors which necessitated this policy shift. First was the ascendancy of John F. Kennedy to the Presidency of the United States in 1961 which coincided with the debates on the implementation of the anti - colonial declaration. The policy shift in United States' approach to colonial issues during the J.F. Kennedy's Presidency was mainly due to his antecedents regarding public declarations on colonialism since the mid-1950s when he realized the growing significance of nationalism on the African continent. According to Rodrigues, Kennedy's presidential ambitions had led him to criticize the record of the Eisenhower administration and to promise that in a future Democratic administration the United States would "no longer abstain in the United Nations from voting on colonial issues ... no longer trade our vote on other such issues for other supposed gains ... No longer seek to prevent subjugated peoples from being heard." (Note 39)

However, despite this declared interest of Kennedy's presidency to help solve the colonial problem in Africa, there was evidence that the United States government under his leadership took that decision for strategic reasons and not necessarily because America wanted to. For instance, President Kennedy repeatedly stated that the United States had "lost ground in Africa" because it had "neglected and ignored the needs and aspirations of the African people" (Note 40). After declaring its interest to assist in the implementation of the colonial declaration, the United States swung into action at the session with the promise to keep the "Cold War" out of the colonialism debate (Kay, 1970). This decision signalled a radical departure from the behaviour of the United States to these issues at the previous session.

The Soviet Union, conscious of America's decision to back the Afro-Asian draft for the implementation of the colonial declaration, quickly agreed not to press its draft resolution for a vote. They decided instead to support the Afro-Asian group's draft version but, however, insisted on the addition of two amendments to the group's draft. The first amendment proposed the year 1962 as "the year of the elimination of colonialism." The first amendment presented by the Soviet Union was antithetical to the outcome of the Afro-Asians draft resolution which was earlier made known at the Assembly. The second amendment proposed by the Soviet Union bloc asked the Special Committee "to make suggestions and recommendations on the immediate application of the Declaration and the completion of its implementation..." (Note 41)

Again, it is evident from the preceding that the prime motive of the Soviet Union was to dislodge the Western colonial powers in Africa at the earliest possible time having realized that the former's continued presence on the continent posed a fundamental threat to their grand plans to make an inroad to Africa. By calling for immediate implementation of the colonial declaration, the Soviet-led Eastern bloc failed to take into consideration the viability and workability of it request. All appeals by the new nations in the Afro-Asian group to have the Soviet Union withdraw the first amendments fell on deaf ears. The stage was then set again for another round of voting in the Assembly. Before this, the leading colonial powers of the time Britain and France unequivocally maintained their earlier position on colonialism. For the British, a policy shift on colonialism would be tantamount to abdicating its 
responsibilities to its colonies and subjects.

The French representatives also indicated that they would not support the draft because it violated the letters and spirit of the UN Charter concerning the obligations of the administering powers to the non-self-governing territories. With the debates on the implementation of the colonial declaration completed, the General Assembly proceeded to vote on the proposal before it. The first proposal to be voted on was the contentious preliminary paragraph of the Soviet Union's amendment that proposed the year 1962 as the terminal date for colonialism. The amendment was routed by a vote of 46 against 19 for, and 35 abstentions (Note 42). The voting pattern on this particular amendment item had a Cold War overtone because all the Western colonial powers still voted against it, even the United States. This act was despite its declared commitment to help solve the colonial crisis. It still found it tough to give support to a draft sponsored by its arch rival - the Soviet Union. The communist states, on the other hand, all voted in support of the draft. The second amendment which was presented for voting was the Soviet Union call for the committee to come up with a timetable which would serve as a guide for immediate implementation of the colonial declaration.

This was also defeated albeit by a mere show of hands in the plenary by a vote of 36 against 22 in favour, and 35 abstaining (Note 43). Suffice to note that this latter amendment, despite its relative temperance, still suffered rejection not only from the West and its sympathizers alone but also from the Afro-Asian group which preferred to stay aloof for fear of being entangled in the Cold War. With the comprehensive defeats of the Soviet Union amendments at the Assembly, it was then time to consider the Afro-Asian draft which had been sponsored by 38 member states of the group. The draft was passed with relative ease by a vote of 97 in favour (the highest obtainable "yes" vote on colonial issue ever in the (UN), none against, and 4 abstentions. The United States which had voted earlier against the Soviet Union amendments threw its weight behind the Afro-Asian draft by voting in favour. Aside the United States, other countries that changed their voting behaviour on the colonial issue included Australia, Belgium, and the Dominican Republic. Those that abstained were South-Africa, United Kingdom, Spain, and France the main holders of the remaining colonial structures at the time. Portugal did not participate in the process at all. The UN General Assembly Resolution 1654 (XVI) of November 1961 entitled "the Situation with Regard to the Implementation of the Declaration on the Granting of Independence to Colonial Countries and Peoples,"44 (Note 44) subsequently became the official position of the United Nations on decolonization.

\section{Conclusion/Recommendation}

The paper has examined the politics of African decolonization in the United Nations and the issues which engendered it using archival and relevant scholarly materials. The findings of this paper have shown that African decolonization was indeed politicized to achieve the Cold War agenda of the rival superpower powers as leaders of both ideological divides leveraged the African colonial problem to advance their national interests. This lands the paper within the realm of realism and international relations theory. The records of UNGA assembly 


\section{Macrothink}

meetings held from 1960-1990 clearly shows that African decolonization issues were politicized by the superpowers and allies respectively.

Going forward, we recommend that Africa should re-make, re-discover and re-engineer itself through social, economic, educational and technological Pan-African interventions that will fire the continent to it destined place among the comity of continents on planet. The African Union (AU), and the New Partnership for African Development (NEPAD) should take the lead forcefully in this respect. The days when African troubles were used as instrument for the pursuit of extra-African imperialistic designs should be gone for good.

\section{References}

Baker, W. B. (1968). The United States and Africa in the United Nations: A Case Study in American Foreign Policy. Imperimerie Offset Composition Services, INC". Washington D.C. (USA).

David, A. K. (1970). The New Nations in the United Nations, 1960-1967. Columbia University Press, New York and London Essex CM20 2JE United Kingdom.

Meredith, M. (2006). The State of Africa, A History of Fifty Years of Independence. FP free Press, London.

Steans, J., \& Pettiford, L. (2001). International Relations: Perspectives and Themes. Pearson Education Limited, England.

Sullivan, C. O. (2005). The United Nations, Decolonization, Self-Determination in Cold War Sub-Saharan Africa, 1960-1994. Journal of Third World Studies, 2.

\section{Notes}

Note 1. For an account of Nikita Khrushchev's Presentation at the Fifteen Session of the UNGA meeting, September-October 1960, see B. Piadyshev, "Khrushchev Stuns the UN," pg. 163 www.mconway.net/page1/page6/.../Khrushchev

Note 2. Ibid, 164.

Note 3. Ibid, 165.

Note 4. Ibid, 170.

Note 5. Ibid, 170.

Note 6. Ibid.

Note 7. Ibid.

Note 8. United Nations General Assembly Official Records, $15^{\text {th }}$ Session 902d meeting (Oct. 12, 1960) para 218.

Note 9. Ibid. 


\section{Macrothink}

Note 10. United Nations Document A/4502, Sept. 23, 1960, Pg. 5.

Note 11. Ibid, Pg. 6.

Note 12. Ibid, Pg. 13.

Note 13. Ibid, Pg. 13.

Note 14. United Nations General Assembly Official Records, $15^{\text {th }}$ Session, $931^{\text {st }}$ meeting (Dec. 13, 1960), para 27-28.

Note 15. United Nations General Assembly Official Records, $15^{\text {th }}$ Session, $926^{\text {th }}$ meeting (Nov. 28, 1960), para 75.

Note 16. United Nations Draft Resolution A/L323, No. 28, 1960.

Note 17. Ibid.

Note 18. Ibid.

Note 19. Ibid.

Note 20. Ibid.

Note 21. United Nations Document A/L.323, Nov. 28, 1960.

Note 22. United Nations General Assembly Official Records $15^{\text {th }}$ Session 925th meeting (Nov. 28, 1960) para 19.

Note 23. United Nations General Assembly Official Records, $15^{\text {th }}$ Session $903 d$ meeting (Oct. 13, 1960\} para. 7-9.

Note 24. United Nations General Assembly Official Records, $15^{\text {th }}$ Session, $926^{\text {th }}$ meeting (Nov. 28, 1960) para. 115.

Note 25. The New Zealand Delegate jumped in Defense of the West to dispel the Notion that Colonialism was out-rightly bad, see, Mr. Shanahan (New Zealand), United Nations General Assembly Official records, $15^{\text {th }}$ Session, 932d meeting (Dec. 2. 1960), para. 4-5.

Note 26. United Nations General Assembly Official Records, $15^{\text {th }}$ Session, $927^{\text {th }}$ meeting (Nov. 29, 1960) para. 15-16.

Note 27. United Nations General Assembly Official Records, $15^{\text {th }}$ Session, $945^{\text {th }}$ meeting (Dec. 13, 1960, para. 33 .

Note 28. United Nations General Assembly Official Records, $15^{\text {th }}$ Session, $931^{\text {st }}$ meeting (Dec. 1, 1960) para. 27-28.

Note 29. Mr.Zorin address to the United Nations General Assembly Official Records, $15^{\text {th }}$ Session, 939 ${ }^{\text {th }}$ meeting (Dec. 7, 1960), para 19-74.

Note 30. United Nations General Assembly Official Records $15^{\text {th }}$ Session 925th meeting (Nov.28, 1960), para 32. 


\section{Macrothink \\ Issues in Social Science \\ ISSN 2329-521X 2020, Vol. 8, No. 2}

Note 31. United Nations General Assembly Official Records $15^{\text {th }}$ Session $937^{\text {th }}$ meeting (Dec. 6. 1960), para 17.

Note 32. United Nations General Assembly Official Records $15^{\text {th }}$ Session 927th meeting (Nov. 29. 1960) para 18.

Note 33. United Nations General Assembly Official Records $15^{\text {th }}$ Session, $947^{\text {th }}$ meeting (Dec. 13, 1960) para 111.

Note 34. United Nations Document A/L.328, (Dec. 13, 1960).

Note 35. United Nations General Assembly, Official Records, $15^{\text {th }}$ Session $947^{\text {th }}$ meeting (Dec. 14. 1960). Para 29.

Note 36. United Nations General Assembly Official Records, $15^{\text {th }}$ Session, $947^{\text {th }}$ meeting (Dec. 14, 1960), para.30.

Note 37. United Nations General Assembly Official Records, $15^{\text {th }}$ Session, $947^{\text {th }}$ meeting (Dec. 14, 1960) para.25.

Note 38. United Nations General Assembly Official Records, $15^{\text {th }}$ Session, $947^{\text {th }}$ meeting (Dec. 14, 1960) para.32.

Note 39. Ibid, para 33.

Note 40. Ibid, para 34.

Note 41. United Nations Document A/4859, Sixteenth Session, August 28, 1961.

Note 42. United Nations Document A/4889, Sixteenth Session, 27 September 1961.

Note 43. United Nations Document A/L.355, Oct. 9, 1961.

Note 44. Ibid para 149.

\section{Copyright Disclaimer}

Copyright for this article is retained by the author(s), with first publication rights granted to the journal.

This is an open-access article distributed under the terms and conditions of the Creative Commons Attribution license (http://creativecommons.org/licenses/by/3.0/). 